\title{
Spectrophotometric Determination of Chloramphenicol in Pharmaceutical Preparations
}

Tamathir A. Hamoudi
Wadala A.

\section{Bashir}

C ollege of Ninevah Medicine

Ninevah University

Department of chemistry

College of Science Mosul Universiy
105/08 تاريخ القبول
2012/06/10 تاريخ الاستلام

2013

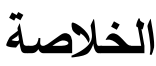

تم اقتراح طريقة طيفية بسيطة وحساسة لتقدير كميات متتاهية في الصغر من الكلورامفينكول. وتعتمد هذه الطريقة على اختزال مجموعة النايترو الموجودة في الكلورامفينكول إلى مجموعة الامينو ثم يقترن الأخير مع كاشف البروميثازين وبوجود ايون السيريوم الرباعي، فتتكون صبغة ملونة تعتمد شدة لونها على كمية الكلورامفينكول الموجودة في المحلول وتمتص عند 606 نانوميتر وبحساسية عالية إذ كانت الإمتصاصية المولارية مساوياً إلى 1.292 ×104 102 لتر .مول -1.1-1 ودلالة ساندل مساوية إلى 0.025 مايكروغرام/سم² ووجد أن قانون بير ينطبق على مدى من التركيز ما بين 0.4 إلى 12 جزء/مليون. و كان الخطأ النسبي ما بين 2.73 إلى 0.37 + \% والانحراف القياسي النسبي ما بين 3.84 التركيز ، وقد طبقت الطريقة بنجاح في تقدير الكلورامفينكول في المستحضرات الصيدلانية (كبسول وقطرة العين ومرهم العين). 


\begin{abstract}
A spectrophotometric method for the determination of trace amounts of chloramphenicol has been proposed. This method depends upon the reduction of the nitro to amino group, condensation with promethazine reagent in the presence of cerium (IV) ions to form a colored dye which exhibits maximum absorption at $606 \mathrm{~nm}$ with a high sensitivity (molar absorptivity is $1.292 \times 10^{4} 1 . \mathrm{mol}^{-1} \cdot \mathrm{cm}^{-1}$, and Sandell's sensitivity index of $0.025 \mu \mathrm{g} / \mathrm{cm}^{2}$ ). Beer' s law is applied within the concentration range of obeyed in 0.4 to $12 \mathrm{ppm}$ with a relative error of -2.73 to $+0.37 \%$ and a relative standard deviation of \pm 3.84 to $\pm 0.44 \%$, depending on the concentration level. The method has been successfully applied to the determination of chloramphenicol in pharmaceutical preparations (capsules, eye drop and eye ointment).
\end{abstract}

\title{
Introduction
}

Chloramphenicol (CAP) (1) is one of the first widely used antibiotics (2).CAP is 2,2-dichloro-N-[(1R,2R)-2-hydroxy-1-(hydroxymethyl)-2-(4nitrophenyl)ethyl]-acetamide (Fig. 1) (3).

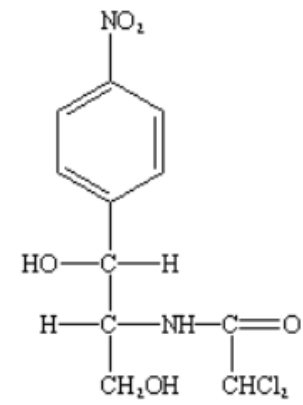

Fig.1. Structure of chloramphenicol

It is a broad spectrum antibiotic which acts by interfering with action of peptidyl transferase after binding to 50S subunit of ribosome and inhibit protein synthesis (3).CAP has been widely used both in medical and veterinary practice, although reasonably safe in domestic animals, however, it is known to exert several side effects in humans such as allergic reactions, gastrointestinal disorders, dose dependent bone narrow depression and grey syndrome in newborns (4). The most serious and potentially lethal effect of chloramphenicol is a plastic anemia (4). Several methods have been reported for the determination of CAP including titration(5), spectrophotometry(2,6-8)biosensor immunoassay (9), gas chromatography $(10,11) \quad, \quad$ liquid chromatography-mass spectrometry(12),liquid chromatography-electrospray ionisation tandem 
mass spectrometry $(13,14)$,enzyme-liquid immunosorbent assay (15-17), molecularly imprinted polymer for HPLC (1), chemiluminescences (18), differential-pulse polagraphy (19) and derivative spectrophotometry (20). Among the various methods available for the determination of the drug, spectrophotometry continues to be very popular, because of its simplicity, specificity and low cost. The present investigation deals with the development of a spectrophotometric method based on oxidative-coupling reaction for the assay of chloramphenicol in pharmaceutical preparation.

\section{Experimental}

\section{Apparatus}

Cintra 5-GBC Scientific Equipment and UV-Visible spectrophotometric. CECIL-CE 1021 digital single beam spectrophotometer with $1.0 \mathrm{~cm}$ matched silica and quartz was used for all absorption measurements.

\section{Reagents}

Chemicals used are of the highest purity available. A pure CAP was obtained from the State Company for Drug Industries and Medical Appliances (SDI), Samara, Iraq.

Chloramphenicol solution $\left(10000 \mu \mathrm{g} \mathrm{ml}^{-1}\right): 0.5 \mathrm{~g}$ of pure CAP was dissolved in a $20 \mathrm{ml}$ of absolute ethanol and diluted the solution to $50 \mathrm{ml}$ with distilled water.

Reduced chloramphenicol $\operatorname{RCAP}\left(500 \mu \mathrm{g} \mathrm{ml}^{-1}\right): 5 \mathrm{ml}$ of $\left(10000 \mu \mathrm{g} \mathrm{ml}^{-1}\right)$ solution was transferred into a $100 \mathrm{ml}$ conical flask, $10 \mathrm{ml}$ of distilled water, $20 \mathrm{ml}$ of hydrochloric acid $(11.55 \mathrm{~N})$ and $4 \mathrm{~g}$ of zinc powder were added. The flask was allowed to stand for 15 minutes and then filled up to the mark with distilled water after filtering the solution.

Reduced chloramphenicol working solution (100 $\left.\mu \mathrm{g} \mathrm{ml}^{-1}\right): 20 \mathrm{ml}$ of reduced CAP solution $\left(500 \mu \mathrm{g} \mathrm{ml}^{-1}\right)$ was transferred, the solution was brought to $\mathrm{pH} 7.0$ with sodium carbonate solution, filtered, then the filtrate solution diluted to $100 \mathrm{ml}$ in a standard volumetric flask.

\section{Procedures for pharmaceutical preparations}

\section{Capsules (BROWN and BURK, (UK) LTD., London)}

The contents of 12 capsules $(250 \mathrm{mg}$ ) were weighed and the powder was mixed. The accurately weighed portion of the powder equivalent to one capsule dissolved in $20 \mathrm{ml}$ of distilled water (with warming). The solution was filtered into a $50 \mathrm{ml}$ calibrated flask. To obtain RCAP solution $5 \mathrm{ml}$ of this solution was transferred and react with zinc powder and hydrochloric acid preceded as a procedure described above. 


\section{Eye drops (REYERLABS, India)}

The contents of five bottles of eye drops $(0.5 \%)$ was mixed. $10 \mathrm{ml}$ of this solution was transferred into a $50 \mathrm{ml}$ calibrated flask and diluted to the mark with distilled water. $25 \mathrm{ml}$ of this solution was transferred and proceeded as procedure for RCAP described above.

\section{Eye ointment (HOLEN)}

The contents of five bottles of eye ointment $(0.1 \%)$ was mixed. $5 \mathrm{~g}$ of this ointment was dissolved in $50 \mathrm{ml}$ of petroleum ether then this solution was extraction using distilling water into 4 portion, each portion contain $50 \mathrm{ml}$ of distilled water. Then filtrated RCAP obtain by using procedure described above.

Promethazine.HCI solution $(\mathbf{0 . 1 \%})$ : The solution was prepared by dissolving $0.1 \mathrm{~g}$ of promethazine.HCl from (SDI) in distilled water and completed to $100 \mathrm{ml}$ in volumetric flask. This solution was store in dark bottle; it is stable for at least one week.

Oxidative reagent solution $(\mathbf{0 . 1 \%})$ : This solution was prepared by dissolving $0.1 \mathrm{~g}$ of Ammonium ceric sulphate dihyrate (ACS) from (BDH) in $100 \mathrm{ml}$ of warm distilled water. This solution was used in the same day. Formic acid solution (1N): This solution was prepared by dilution $9.6 \mathrm{ml}$ of concentrated formic acid $(25.97 \mathrm{~N})$ (Fulka) with distilled water to the mark in $250 \mathrm{ml}$ volumetric flask.

Excipient drugs (1000 ppm): This solution was prepared by dissolving $0.1 \mathrm{~g}$ in $100 \mathrm{ml}$ of distilled water.

\section{General procedure and Calibration graph}

The aqueous solution of RCAP contains (10-700) $\mu \mathrm{g}$ was transferred to $25 \mathrm{ml}$ calibration flask. A $4 \mathrm{ml}$ of promethazine. $\mathrm{HCl}$ reagent $(0.1 \%)$ solution, $5 \mathrm{ml}$ of formic acid (1N) then $8 \mathrm{ml}$ of oxidative reagent (cerium IV) $(0.1 \%)$ were added and the volume was made up to the mark with distilled water. The absorbance measured after 15 minute at $606 \mathrm{~nm}$ against a blank solution which was prepared in a similar way but without the addition of RCAP. The calibration graph as shown in Fig. (2) was liner over the range of (10-300) $\mu \mathrm{g}$ of RCAP/25 ml (0.4-12 ppm). Higher concentration showed a negative deviation from Beer's law. The apparent molar absorpitivity referred to RCAP $1.292 \times 10^{4} 1 . \mathrm{mol}^{-1} . \mathrm{cm}^{-1}$ and Sandel's sensitivity is equal to $0.025 \mu \mathrm{g} / \mathrm{cm}$. 


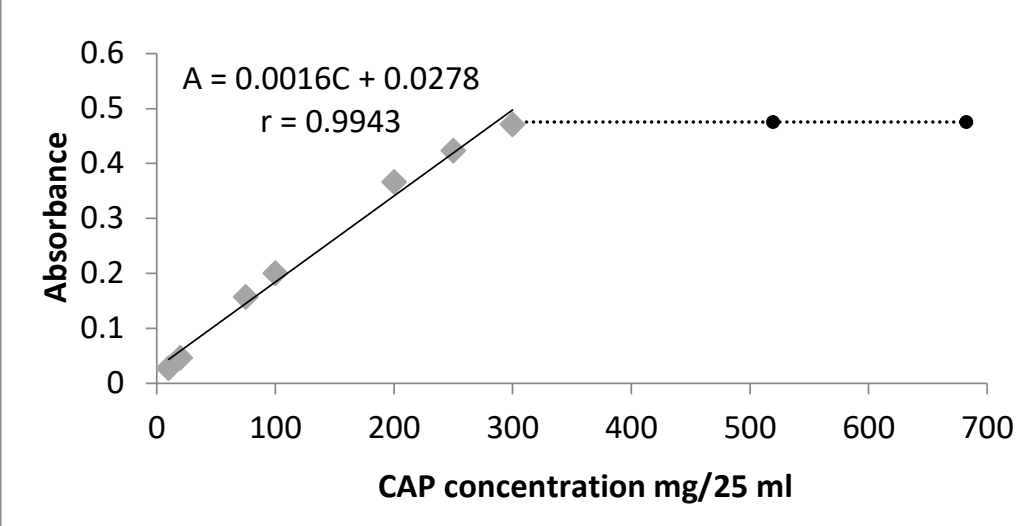

Fig.2Calibration graph for CAP determination using the proposed method Results and discussion

The effect of various variables on the color development was tested to establish the optimum conditions for determination of CAP by oxidative coupling with promethaizne. $\mathrm{HCl}$ reagent.

\section{Principle of the method}

The method involves two steps:

Step 1: Oxidation of promethazine. $\mathrm{HCl}$ reagent to give a red intermediate. Step 2: The intermediate couples with reduced CAP to form a blue-green color.

\section{The effect of acids}

Effect of different acids has been studied on the intensity of dye; the results are shown in (Table 1). $5 \mathrm{ml}$ of formic acid (1N) has been chosen in the next experiments. Because in formic acid, the reaction becomes less sensitive to media environment than others and the formation of the greenish-blue dye is not affected by acid amount.

Table 1. Effect of different acids on absorbance

\begin{tabular}{|c|c|c|c|c|c|c|c|c|c|c|}
\hline \multirow{2}{*}{$\begin{array}{l}\text { Ml of } \\
\text { acid }\end{array}$} & \multicolumn{2}{|c|}{$\begin{array}{c}\mathrm{HCl} \\
(\mathbf{1 N}) \\
\end{array}$} & \multicolumn{2}{|c|}{$\begin{array}{c}\mathrm{H}_{2} \mathrm{SO}_{4} \\
(\mathbf{1 N})\end{array}$} & \multicolumn{2}{|c|}{$\begin{array}{c}\mathrm{H}_{3} \mathrm{PO}_{4} \\
(\mathbf{1 N}) \\
\end{array}$} & \multicolumn{2}{|c|}{$\begin{array}{c}\mathrm{CH}_{3} \mathrm{COOH} \\
(1 \mathrm{~N})\end{array}$} & \multicolumn{2}{|c|}{$\begin{array}{c}\text { HCOOH } \\
(\mathbf{1 N})\end{array}$} \\
\hline & $\overline{A^{*}}$ & pH & $\bar{A}$ & $\mathbf{p H}$ & $\bar{A}$ & pH & $\mathbf{A}$ & pH & $\mathbf{A}$ & pH \\
\hline 05 & 0.326 & & & & & & & & 330 & 1.86 \\
\hline & & 1. & 315 & & 280 & & 36 & & 332 & 1.8 \\
\hline 2.0 & & & 0.300 & & 270 & 1.4 & 0.355 & .52 & .336 & 1.84 \\
\hline 3.0 & 296 & 0.80 & 0.282 & 0. & 369 & 1.40 & 0.348 & 1.54 & 0.324 & 1.83 \\
\hline 5 & 287 & 0.6 & 263 & 0.7 & 324 & 1.3 & 0.360 & 1.53 & 0.331 & 1.82 \\
\hline 7.0 & 0.294 & 0.50 & 0.276 & 0.68 & 0.330 & 1.28 & 0.359 & 1.53 & 0.328 & 1.79 \\
\hline 0.0 & 0.283 & 0.36 & 0.280 & 0.53 & 0.339 & 1.22 & 0.373 & 1.50 & 0.320 & 1.79 \\
\hline
\end{tabular}

$* \mathrm{~A}=$ Absorbance of sample 
Spectrophotometric Determination of Chloramphenicol in Pharmaceutical ...

\section{Choice the reagent}

Several different reagents $\left(3.1 \times 10^{-3} \mathrm{~N}\right)$ have been studied with $4 \mathrm{ml}$ of each, and also $7 \mathrm{ml}$ of sodium hydroxide $(1 \mathrm{~N})$ instead of $5 \mathrm{ml}$ acid also have been studied. The results are shown in (Tables $2 \mathrm{a}, 2 \mathrm{~b}, 2 \mathrm{c}, 2 \mathrm{~d}$ ).

Table 2a . Test and selection of coupling agent in the presence of $5 \mathrm{ml}$ of $1 \mathrm{M}$ HCl

\begin{tabular}{||l|c|c|c|c||}
\hline \multirow{2}{*}{ Coupling agents } & \multicolumn{2}{c|}{ Color of } & \multicolumn{2}{c|}{ Absorbance of } \\
\cline { 2 - 5 } & Sample & Blank & Sample & Blank \\
\hline 4-Aminophenol & Light- Brown & Brown & -0.084 & 0.142 \\
\hline 1,10-Phenanthroline & ---- & ---- & --- & ---- \\
\hline p-Phenylenediamine & Light-pink & Light-Brown & -0.045 & 0.059 \\
\hline Phloroglucinol & ---- & --- & ---- & ---- \\
\hline Promethazine.HCl & Blue-green & Red & 0.287 & 0.051 \\
\hline Thymol & ---- & ---- & ---- & ---- \\
\hline
\end{tabular}

Table $2 \mathrm{~b}$. Test and selection of coupling agent in the presence of $5 \mathrm{ml}$ of $1 \mathrm{M}$ formic acid

\begin{tabular}{||l|c|c|c|c||}
\hline \multirow{2}{*}{ Coupling agents } & \multicolumn{2}{c|}{ Colour of } & \multicolumn{2}{c|}{ Absorbance of } \\
\cline { 2 - 5 } & Sample & Blank & Sample & Blank \\
\hline 4-Aminophenol & Light- Brown & Brown & -0.084 & 0.142 \\
\hline $1,10-$-Phenanthroline & ---- & ---- & --- & ---- \\
\hline p-Phenylenediamine & Light-pink & Light-Brown & -0.045 & 0.059 \\
\hline Phloroglucinol & --- & --- & ---- & ---- \\
\hline Promethazine.HCl & Blue-green & Red & 0.287 & 0.051 \\
\hline Thymol & ---- & ---- & ---- & ---- \\
\hline
\end{tabular}

Table 2c. Test and selection of coupling agent in the presence of $5 \mathrm{ml}$ of $1 \mathrm{M}$ of phosphoric acid

\begin{tabular}{|l||c|c||c|c||}
\hline \multirow{2}{*}{ Coupling agents } & \multicolumn{2}{c|}{ Color of } & \multicolumn{2}{c|}{ Absorbance of } \\
\cline { 2 - 5 } & Sample & Blank & Sample & Blank \\
\hline 4-Aminophenol & $\begin{array}{c}\text { Light- } \\
\text { Brown }\end{array}$ & Brown & -0.077 & 0.135 \\
\hline $1,10-$ Phenanthroline & ---- & ---- & ---- & ---- \\
\hline p-Phenylenediamine & Light-pink & Light-Brown & -0.057 & 0.071 \\
\hline Phloroglucinol & ---- & ---- & ---- & ---- \\
\hline Promethazine.HCl & Green -Blue & Pink & 0.324 & 0.066 \\
\hline Thymol & ---- & ---- & ---- & ---- \\
\hline
\end{tabular}


Table 2d . Test and selection of coupling agent in the presence of $7 \mathrm{ml}$ of sodium hydroxide instead of $5 \mathrm{ml}$ of acid

\begin{tabular}{||l||c|c||c|c||}
\hline \multirow{2}{*}{ Coupling agents } & \multicolumn{2}{c||}{ Color of } & \multicolumn{2}{c|}{ Absorbance of } \\
\cline { 2 - 5 } & Sample & Blank & Sample & Blank \\
\hline 4-Aminophenol & Brown & Brown & -0.007 & 0.411 \\
\hline 1,10-Phenanthroline & ---- & ---- & ---- & ---- \\
\hline p-Phenylenediamine & Brown & Orange & 0.164 & 0.071 \\
\hline Phloroglucinol & Pale-yellow & Pale-yellow & 0.010 & 0.035 \\
\hline Promethazine.HCl & ---- & ---- & ---- & ---- \\
\hline Thymol & ---- & ---- & ---- & ---- \\
\hline
\end{tabular}

From the results it is clear that promethazine give high results in selectivity and color contrast, its solution is easy to prepare and stable therefore it used for next experiments.

\section{Effect of reagent amount}

The effect of reagent amount on sensitivity of method has been studied. A series of solutions contain different volume of promethazine $(0.1 \%)$ reagent with different amounts of RCAP have been made. The results are shown in (Table 3). $4 \mathrm{ml}$ of the reagent have been chosen from the results obtained because the sensitivity of the reaction is good, the absorbance and correlation coefficient is excellent as well as the absorbance of blank is low. 
Spectrophotometric Determination of Chloramphenicol in Pharmaceutical ...

Table 3. The effect of reagent amount on the absorbance of dye formed

\begin{tabular}{|c|c|c|c|c|c|c|c|c|c|c|}
\hline \multirow{2}{*}{$\begin{array}{l}\text { Ml of } 0.1 \% \\
\text { promethazine.HCl } \\
\text { solution }\end{array}$} & \multicolumn{7}{|c|}{ Absorbance / $\mu$ g of CAP present } & \multirow[b]{2}{*}{$\mathbf{r}_{20}-\mathbf{5 0 0}$} & \multirow[b]{2}{*}{$\mathbf{r}_{20}-\mathbf{2 0 0}$} & \multirow[b]{2}{*}{$\mathbf{r}_{40-200}$} \\
\hline & 20 & 40 & 70 & 100 & 200 & 300 & 500 & & & \\
\hline 0.5 & 0.045 & 0.079 & 0.114 & 0.130 & 0.101 & 0.086 & 0.057 & 0.25358 & 0.52578 & 0.19590 \\
\hline 1.0 & 0.046 & 0.086 & 0.145 & 0.192 & 0.240 & 0.226 & 0.170 & 0.54296 & 0.93931 & 0.93573 \\
\hline 2.0 & 0.048 & 0.089 & 0.152 & 0.205 & 0.331 & 0.350 & 0.343 & 0.84519 & 0.99149 & 0.99270 \\
\hline 3.0 & 0.047 & 0.089 & 0.151 & 0.206 & 0.355 & 0.390 & 0.369 & 0.85152 & 0.99638 & 0.99722 \\
\hline 4.0 & 0.050 & 0.092 & 0.154 & 0.213 & 0.372 & 0.424 & 0.417 & 0.88064 & 0.99762 & 0.99797 \\
\hline 6.0 & 0.054 & 0.090 & 0.150 & 0.214 & 0.371 & 0.419 & 0.443 & 0.90623 & 0.99781 & 0.99745 \\
\hline 8.0 & 0.043 & 0.086 & 0.153 & 0.210 & 0.381 & 0.444 & 0.471 & 0.91375 & 0.99803 & 0.99847 \\
\hline 10.0 & 0.058 & 0.089 & 0.152 & 0.214 & 0.370 & 0.433 & 0.451 & 0.90987 & 0.99775 & 0.99704 \\
\hline
\end{tabular}




\section{Choice of oxidative reagent}

Number of oxidative reagent $\left(1.5 \times 10^{-3} \mathrm{M}\right)$ in $4 \mathrm{ml}$ has been studied on the absorbance of dye contained; the results are shown in (Table 4).

Table 4. Test and selection of oxidative reagent

\begin{tabular}{||l||c|c||c|c||c||}
\hline \multirow{2}{*}{ Oxidative reagent } & \multicolumn{2}{|c||}{ Color of } & \multicolumn{2}{|c|}{ Absorbance of } & \multirow{2}{*}{ pH } \\
\cline { 2 - 5 } & Sample & Blank & Sample & Blank & \\
\hline $\begin{array}{l}\text { Ammonium ceric } \\
\text { sulphate }\end{array}$ & $\begin{array}{c}\text { Blue- } \\
\text { green }\end{array}$ & Pink & 0.350 & 0.065 & 1.38 \\
\hline $\begin{array}{l}\text { Ammonium } \\
\text { metavanadate }\end{array}$ & $\begin{array}{c}\text { v.light } \\
\text { blue }\end{array}$ & Light pink & 0.030 & 0.021 & 2.51 \\
\hline Potassium dichromate & Light blue & $\begin{array}{c}\text { v.light } \\
\text { orange }\end{array}$ & 0.132 & 0.009 & 2.47 \\
\hline Potassium ferricyanide & ---- & ---- & Turbid & ---- & ---- \\
\hline Potassium iodate & Dark blue & Colourless & 0.329 & 0.009 & 1.78 \\
\hline Potassium periodate & Dark blue & Colourless & 0.466 & 0.004 & 2.11 \\
\hline Sodium nitrite & Light pink & Light pink & 0.016 & 0.004 & 2.76 \\
\hline
\end{tabular}

*The sample became dark turbid blue upon addition of formic acid, while the blank remains yellow.

The results shown in (Table 4) show high absorbance for potassium iodate and potassium periodate consider to the blank which give low absorbance, which are not used because they give unstable products. ACS still used for next experiments.

\section{Effect of oxidative reagent amount}

Different volumes of oxidative reagent ACS (0.1\%) have been studied on the absorbance of solution contain different volumes of RCAP. Table 5 shows $8 \mathrm{ml}$ was the best therefore it was used for the next experiments.

\section{Effect of surfactant}

The effect of several types of surfactants on color intensity of the colored product has been investigated. The results indicate that addition of surfactants give no several effect [increasing the intensity or improving the color contrast $(\Delta \lambda)]$, therefore it has not been used in the subsequent experiments. 
Table 5 .Effect of oxidative reagent amount

\begin{tabular}{|c|c|c|c|c|c|c|c|c|c|c|}
\hline \multirow{2}{*}{$\begin{array}{l}\text { Ml of } 0.1 \% \\
\mathrm{Ce}^{+4} \text { solution }\end{array}$} & \multicolumn{7}{|c|}{ Absorbance / $\mu \mathrm{g}$ of CAP present } & \multirow[b]{2}{*}{$\mathbf{r}_{20}-\mathbf{5 0 0}$} & \multirow[b]{2}{*}{$\mathbf{r}_{20}-\mathbf{2 0 0}$} & \multirow[b]{2}{*}{$\mathbf{r}_{40}-200$} \\
\hline & 20 & 40 & 70 & 100 & 200 & 300 & 500 & & & \\
\hline 0.5 & 0.036 & 0.050 & 0.064 & 0.067 & 0.070 & 0.068 & 0.059 & 0.39607 & 0.80251 & 0.78796 \\
\hline 1.0 & 0.042 & 0.078 & 0.107 & 0.123 & 0.129 & 0.129 & 0.118 & 0.58157 & 0.82270 & 0.82420 \\
\hline 2.0 & 0.049 & 0.085 & 0.145 & 0.185 & 0.242 & 0.247 & 0.233 & 0.76983 & 0.95227 & 0.95090 \\
\hline 3.0 & 0.046 & 0.086 & 0.148 & 0.213 & 0.330 & 0.354 & 0.353 & 0.85675 & 0.98778 & 0.98723 \\
\hline 4.0 & 0.044 & 0.086 & 0.149 & 0.211 & 0.370 & 0.428 & 0.447 & 0.90590 & 0.99715 & 0.99743 \\
\hline 6.0 & 0.045 & 0.086 & 0.149 & 0.210 & 0.395 & 0.521 & 0.574 & 0.94669 & 0.99951 & 0.99957 \\
\hline 8.0 & 0.050 & 0.085 & 0.146 & 0.204 & 0.409 & 0.587 & 0.744 & 0.98169 & 0.99983 & 0.99996 \\
\hline 10.0 & 0.041 & 0.081 & 0.137 & 0.192 & 0.396 & 0.571 & 0.755 & 0.98689 & 0.99976 & 0.99706 \\
\hline
\end{tabular}




\section{Order of addition}

The order of additions of reagent $(\mathrm{C}, \mathrm{P}, \mathrm{O}$ and $\mathrm{A})$ was examined. The results shown in (Table 6) indicated that the order (VII) of addition of reagents was the optimum order due to the high intensity of the formed dye.

Table 6 . Effect of order of addition

\begin{tabular}{|c|c||c|c|}
\hline Reaction components & \multirow{2}{*}{$\begin{array}{c}\text { Order } \\
\text { number }\end{array}$} & \multicolumn{2}{|c|}{ Absorbance } \\
\cline { 3 - 4 } & & Sample & Blank \\
\hline \hline $\mathrm{C}+\mathrm{P}+\mathrm{O}+\mathrm{A}^{*}$ & $\mathrm{I}$ & 0.402 & 0.135 \\
\hline $\mathrm{C}+\mathrm{O}+\mathrm{P}+\mathrm{A}$ & $\mathrm{II}$ & 0.401 & 0.137 \\
\hline $\mathrm{C}+\mathrm{A}+\mathrm{P}+\mathrm{O}$ & $\mathrm{III}$ & 0.410 & 0.127 \\
\hline $\mathrm{C}+\mathrm{A}+\mathrm{O}+\mathrm{P}$ & $\mathrm{IV}$ & 0.005 & 0.127 \\
\hline $\mathrm{P}+\mathrm{O}+\mathrm{C}+\mathrm{A}$ & $\mathrm{V}$ & 0.444 & 0.157 \\
\hline $\mathrm{P}+\mathrm{A}+\mathrm{C}+\mathrm{O}$ & VI & 0.418 & 0.154 \\
\hline $\mathrm{P}+\mathrm{A}+\mathrm{O}+\mathrm{C}$ & VII & 0.451 & 0.155 \\
\hline $\mathrm{O}+\mathrm{C}+\mathrm{A}+\mathrm{P}$ & $\mathrm{VIII}$ & 0.413 & 0.147 \\
\hline $\mathrm{O}+\mathrm{A}+\mathrm{C}+\mathrm{P}$ & $\mathrm{IX}$ & 0.409 & 0.142 \\
\hline $\mathrm{O}+\mathrm{P}+\mathrm{A}+\mathrm{C}$ & $\mathrm{X}$ & 0.427 & 0.151 \\
\hline $\mathrm{A}+\mathrm{O}+\mathrm{P}+\mathrm{C}$ & $\mathrm{XI}$ & 0.437 & 0.139 \\
\hline
\end{tabular}

\section{Effect of time}

The effect of time on the development and stability period of the formed colored product was investigated under optimum experiment conditions described before. The formation of colored product being complete after mixing the component of reaction and the absorbance of the colored species remained constant for, at least 45 minute. Fifteen mintutes have been recommended as a formation colored product for the subsequent experiments. (Table 7). 
Table 7 .Effect of time on absorption

\begin{tabular}{|c|c|c|c|c|c|c|c|c|c|c|c|c|c|}
\hline \multirow{2}{*}{$\begin{array}{r}\mu \mathrm{gAP} / \\
25 \mathrm{ml}\end{array}$} & \multicolumn{13}{|c|}{ bsorbance / minute standing time } \\
\hline & $\mathbf{0}$ & 5 & 10 & 15 & 20 & 25 & 30 & 35 & 40 & 45 & 50 & 55 & 60 \\
\hline 20 & 0.058 & 0.059 & $\mathbf{0 . 0 5 3}$ & 0.054 & 0.056 & 0.055 & 0.055 & 0.055 & $\mathbf{0 . 0 5 7}$ & 0.057 & $\mathbf{0 . 0 5 7}$ & 0.058 & 0.060 \\
\hline 50 & 0.137 & 0.134 & 0.131 & 0.130 & 0.134 & 0.129 & 0.131 & 0.133 & 0.135 & 0.135 & 0.136 & 0.140 & 0.143 \\
\hline 100 & 0.219 & 0.228 & 0.233 & 0.231 & 0.234 & 0.230 & 0.231 & 0.231 & 0.234 & 0.234 & 0.235 & 0.237 & 0.237 \\
\hline 200 & 0.343 & 0.422 & 0.434 & 0.435 & 0.439 & 0.439 & 0.439 & 0.443 & 0.443 & 0.445 & 0.446 & 0.447 & 0.449 \\
\hline 300 & 0.347 & 0.522 & 0.558 & 0.577 & 0.587 & 0.595 & 0.607 & 0.610 & 0.617 & 0.621 & 0.626 & 0.628 & 0.633 \\
\hline 500 & 0.420 & 0.623 & 0.673 & 0.694 & 0.705 & 0.716 & 0.726 & 0.735 & 0.744 & 0.752 & 0.762 & 0.771 & 0.777 \\
\hline
\end{tabular}




\section{Final absorption spectrum}

After addition of RCAP to solution contain promethazine reagent, ACS (IV) and formic acid under optimum conditions described before, colored product was formed, shows a maximum absorption at $606 \mathrm{~nm}$ in contrast to the reagent blank. The maximum wavelength $606 \mathrm{~nm}$ has been used in the subsequent experiments. (Fig. 3).

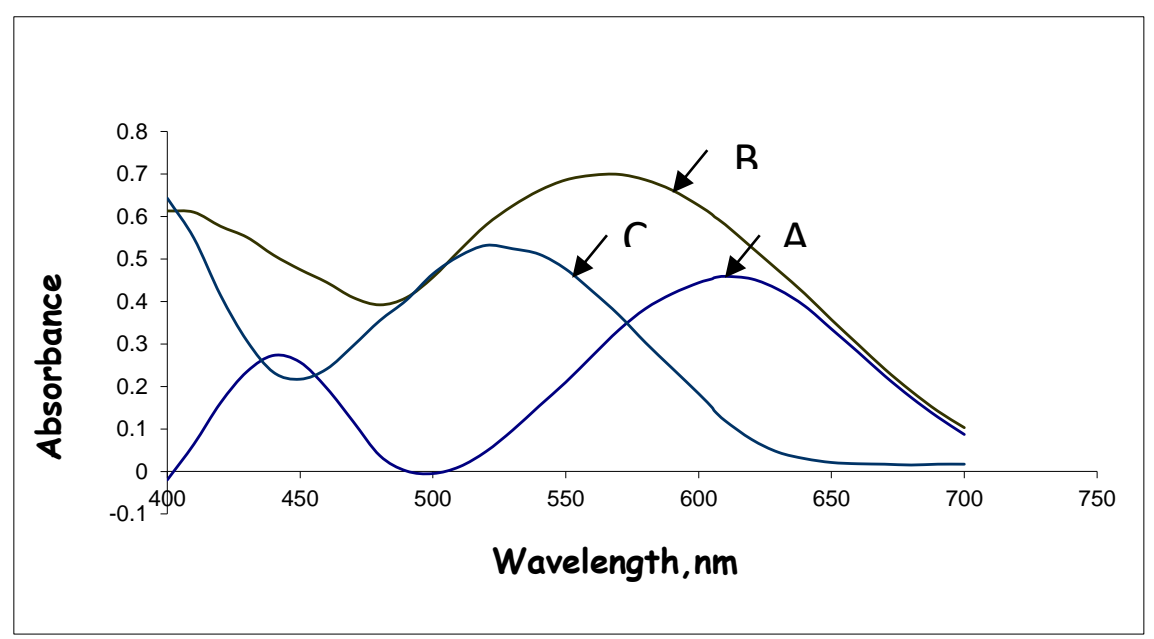

Fig 3. Absorption spectra of $200 \mu \mathrm{g} / 25 \mathrm{ml}$ of CAP (treated according to the recommended procedure) against (A) blank (B) distilled water and (C) blank measured against distilled water.

\section{Effect of some excipients on the assay of CAP}

To test the efficiency and selectivity of the proposed analytical method, a systematic study of excipients that usually present in dosage showed that there was no interference from excipients up to $1000 \mu \mathrm{g}$ in the present method as shown in (Table 8).

Table 8 . Effect of some excipients on the assay of CAP

\begin{tabular}{|c|c|c|c|c|}
\hline \multirow[t]{2}{*}{ Excipient } & \multicolumn{4}{|c|}{$\begin{array}{c}\text { Recovery } \%, \text { of } 200 \mu \mathrm{g} \text { of CAP per } \mu \mathrm{g} \text { of excipient } \\
\text { Added }\end{array}$} \\
\hline & $100 \mu \mathrm{g}$ & $300 \mu \mathrm{g}$ & $500 \mu \mathrm{g}$ & $1000 \mu \mathrm{g}$ \\
\hline Vanillin & 98.3 & 103.2 & 95.6 & 100 \\
\hline Glucose & 104.7 & 99.5 & 101.5 & 97.0 \\
\hline Dextrose & 99.5 & 98.5 & 101.7 & 99.5 \\
\hline Gum acacia & 100.3 & 98.7 & 100.5 & 100 \\
\hline Starch & 98.5 & 99.8 & 101 & 100.7 \\
\hline Lactose & 102.1 & 98.4 & 99.5 & 99.5 \\
\hline CTAB & 102.3 & 101 & 105.5 & 107.5 \\
\hline Sucrose & 98.8 & 101.5 & 98.5 & 100.3 \\
\hline Tween -80 & 99.5 & 97.0 & 100.7 & 98.6 \\
\hline Glycerol & 97.8 & 95.4 & 99.0 & 95.9 \\
\hline
\end{tabular}




\section{Accuracy and precision}

To check the accuracy and precision of the calibration curve, CAP was determined at three different concentrations. The results (illustrated in Table 9) indicated that the method is satisfactory.

Table 9. Accuracy and precision of the calibration curve

\begin{tabular}{|c|c|c|}
\hline $\begin{array}{c}\text { Amount of CAP } \\
\text { taken, } \boldsymbol{\mu g}\end{array}$ & $\begin{array}{c}\text { Relative error, } \\
\boldsymbol{\%}^{*}\end{array}$ & $\begin{array}{c}\text { Relative standard } \\
\text { deviation, \% }\end{array}$ \\
\hline 20 & -2.73 & \pm 3.84 \\
\hline 100 & +2.43 & \pm 4.01 \\
\hline 200 & +0.37 & \pm 0.44 \\
\hline
\end{tabular}

*Average of five determinations.

\section{Nature of Dye}

Job's method (21) indicates that the colored product has a composition of 1:2 CAP to promethazine reagent (Fig 4).

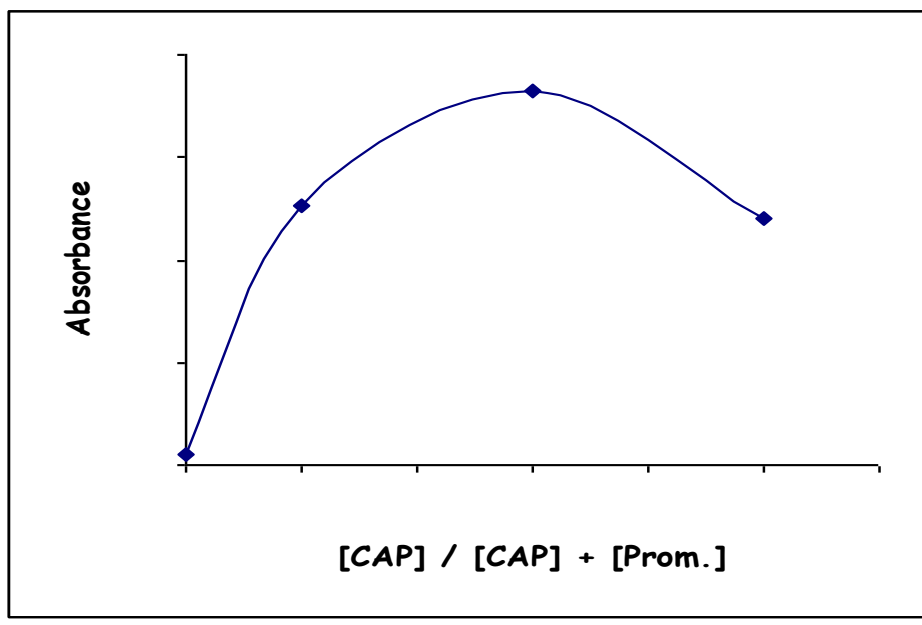

Fig 4 . Job's plot for CAP with promethazine solution

Hence, the colored product may have the following structure.

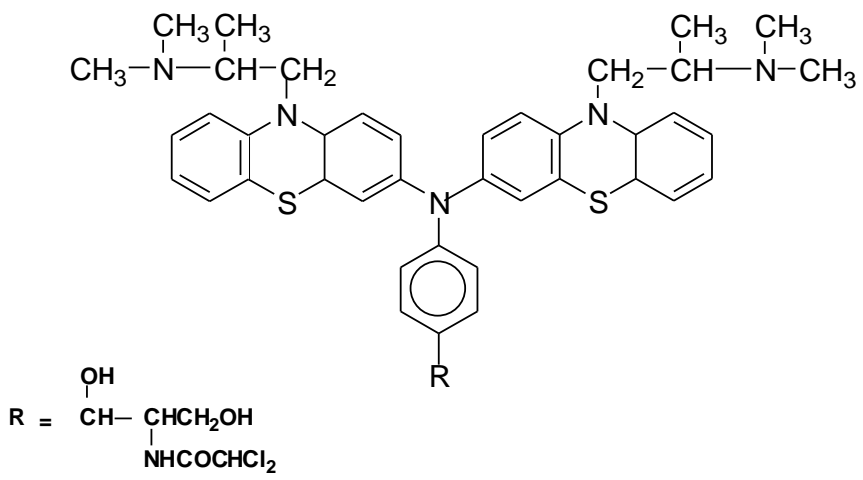




\section{Effect of organic solvent}

Different organic solvents have been used to examine their effects on the dye. The results are shown in (Table 10) .

Table 10. Effect of solvents

\begin{tabular}{|c|c|c|}
\hline Solvents & $\lambda_{\max }, \mathbf{n m}$ & $\varepsilon, 1 . \mathrm{mol}^{-1} \cdot \mathrm{cm}^{-1}$ \\
\hline Acetic acid & 610 & $1.73 \times 10^{4}$ \\
\hline Acetone & Turbid & ---- \\
\hline Dioxane & 610 & $1.85 \times 10^{4}$ \\
\hline DMSO & 610 & $1.78 \times 10^{4}$ \\
\hline Ethanol & 610 & $1.66 \times 10^{4}$ \\
\hline Formic acid & 620 & $0.93 \times 10^{4}$ \\
\hline Iso-butanol & Two layer & ---- \\
\hline Methanol & 610 & $1.69 \times 10^{4}$ \\
\hline n-Propanol & 610 & $1.72 \times 10^{4}$ \\
\hline Pyridine & 540 & $1.08 \times 10^{4}$ \\
\hline T.H.F & 600 & $1.59 \times 10^{4}$ \\
\hline Water & 606 & $1.36 \times 10^{4}$ \\
\hline
\end{tabular}

According to its good sensitivity and low cost water has been used for dilution.

\section{Application of the method}

The proposed method was successfully applied to determine CAP in its pharmaceutical preparations (capsule, eye drop and eye ointment) (Table11) from different sources. This method was compared with the NNED (22) method. The results showed that there was no significant difference between the proposed and N-NED method.

Table 11. Analytical applications of determination of CAP in pharmaceutical preparations.

\begin{tabular}{||l|c|c|}
\hline \multirow{2}{*}{ Pharmaceutical preparation } & \multicolumn{2}{|c|}{ Recovery \%* } \\
\cline { 2 - 3 } & Present method & N-NED method \\
\hline Capsule & 98.5 & 94.76 \\
\hline Eye drop & 100 & 116.8 \\
\hline Eye ointment & 99.2 & 95.24 \\
\hline
\end{tabular}

\section{Comparison of methods}

$$
\text { *Average of three determinations }
$$

Table (12) shows the comparison between some of analytical variables for the present method with that of other spectrophotometric methods. Table 12 . Comparison of the methods 


\begin{tabular}{|c|c|c|c|}
\hline Analytical parameters & Literature method $^{(23)}$ & N-NED ${ }^{(22)}$ & Present method \\
\hline $\mathrm{pH}$ & $\begin{array}{c}\text { Acid } \\
\text { Medium }\end{array}$ & $\begin{array}{c}\text { Acid } \\
\text { Medium }\end{array}$ & $\begin{array}{c}\text { Acid } \\
\text { medium }\end{array}$ \\
\hline$\lambda_{\max },(\mathrm{nm})$ & 600 & 550 & 606 \\
\hline Temperature $\left(\mathrm{C}^{\circ}\right)$ & $\begin{array}{c}\text { At room } \\
\text { Temperature }\end{array}$ & $\begin{array}{c}\text { At room } \\
\text { temperature }\end{array}$ & $\begin{array}{c}\text { At room } \\
\text { temperature }\end{array}$ \\
\hline Development time ( $\min$. ) & 30 & 10 & 15 \\
\hline Reagent used & Promethazine.HCI & N-NED & Promethazine.HCI \\
\hline Stability period ( hour ) & 5 & 8 & 45 minute at least \\
\hline$\varepsilon, 1 . \mathrm{mol}^{-1} . \mathrm{cm}^{-1}$ & $1.87 \times 10^{4}$ & ---- & $1.292 \times 10^{4}$ \\
\hline Beer 's law range(ppm) & $0.4-10$ & $0.8-8$ & $0.4-12$ \\
\hline Average recovery ( $\%$ ) & --- & 99.6 & 99.92 \\
\hline $\operatorname{RSD}(\%)$ & \pm 2.0 & \pm 1.0 & \pm 3.8 to \pm 0.44 \\
\hline Correlation coefficient & 0.9981 & --- & 0.9943 \\
\hline Toxicity of reagent ${ }^{*}$ & Safe $^{a}$ & $\begin{array}{c}\text { Irritant \& } \\
\text { hygroscopic }\end{array}$ & Safe $^{\mathrm{a}}$ \\
\hline Analytical application & $\begin{array}{l}\text { Pharmaceutical } \\
\text { preparations }\end{array}$ & $\begin{array}{l}\text { Pharmaceutical } \\
\text { preparations }\end{array}$ & $\begin{array}{c}\text { Pharmaceutical } \\
\text { preparations }\end{array}$ \\
\hline
\end{tabular}

* Aldrich, "Catalog Handbook of Fine Chemicals," Aldrich Chemical Company, Inc., Wisconsin, (1990 - 1991) , pp.(a) : 1101, (b) : 941

The results indicate that the proposed method is not less efficient than other methods

\section{Conclusion}

The determination of chroramphenicol in pharmaceutical preparations has been developed. The method is based on the oxidative-coupling reaction of the drug with promethazine. $\mathrm{HCl}$ in the presence of cerium (IV) ion. The blue-green color formed is measured as a function of drug amount. The accuracy of the method has been tested by its application to assay of chloramphenicol in pharmaceutical preparations (capsules, eye drop and eye ointment) and found to be successful.

\section{References}

1) Kowalski D., Poboży E. and Trojanowicz M., J. Auto. Meth. Manage. Chem., 2011: 10 pages, (2011).

2) Ebok C. J., Smart J. and Adelusi S. A., Trop. J. Pharm. Res., 2: 215221,(2003).

3) Yasin M. N., Hussain S., Malik F. , Hameed A., Sultan T., Qureshi F., Riaz1 H., Perveen G. and Wajid A., Pak. J. Pharm. Sci., 25: 117-121, (2012).

4) Mehdizadeh S. , Kazerani H. R. and Jamshidi A., IJVST, 2 : 25-32, (2010).

5) Talegaonkar J., Mukhija S. and Boparai K. S., Hind. Antibiot. Bull. , 24 : 24-25, (1982). 
6) Al-Sabha Th. N. and Rasheed B. A., JJC, 5: 201-210, (2010).

7) Naik S. D., Nagaraja P., Yathirajan H. S., Hemanthakumar M. S. and Mohan B. M., Pharm. Chem. J., 40 : 576-581,(2006).

8) Al-Abachi M. Q., Al-Ghabsha T. S. and Salih E. S., J. Edu. Sci. , 25: 5-12, (1996) .

9) Gaudin V. and Maris P., Food Agr. Imm., 13: 77-86, (2001).

10) Ding S., Shen J., Zhang S., Jiang H., Sun Z., J. AOAC Int., 88: 57-60, (2005).

11) Pfenning A. P., Roybal J. E., Rupp H. S., Turnipseed S. B., Gonazales S.A. and Hurlbut J. A., J. AOAC. Int., 83: 26-30, (2000).

12) Riet vav de J. M., Potter R. A., Fougere M.C. and Burns B. G., J. AOAC. Int., 86: 510-514, (2003).

13) Musa A. , Yakasai I. A., Garba M. and Mathias B. K., J. Bas. Clin. Pharm., 1: 97-101, (2010).

14) Tyagi A., Vernekar P., Karunasagar I., Karunasagar I., Food addit. Contam. Part A, 25 : 432-437, (2008).

15) Wang L., Zhang Y., Gao X., Duan Z. and Wang Sh., J. Agric. Food Chem., 58 : 3265-3270,(2010).

16) Kucharska U. and Leszczynska J., Chem. Listy., 94: 190-194, (2000).

17) Reybroeck W., Apiacta, 38: 23-30, (2003).

18) Lindino C. A. , Bulhões L. O. S., J. Braz. Chem. Soc., 15 : ISSN 0103-5053, (2004).

19) Duda J.and Kucharska U., Anal. Lett. , 32 : 1049-1064, (1999) .

20) Nevado J. J. B., Flores J. R. and Pardo M. L. M., Fres. J. Anal. Chem., 349: 756-760, (1994).

21)Delevie R., Principles of quantitative chemical analysis, McGraw-Hill Internatiional Edition, Singapore, 498, (1997).

22) Hassan S. S. M. and Eldesouki M. H., Talanta, 26: 531-536, (1979).

23) Al-Abachi M. Q., Akrawi B. A., Salih E. S. and Shihab Y. M., Mu'tah J.Res. Stu., 7: 163-173, (1992). 